\title{
Effect of Health Education on Health Behavior in Patients with Hypertension
}

\author{
Nur Haryani'), AA. Subiyanto ${ }^{2)}$, Nunuk Suryani3) \\ 1) School of Public Health, Sebelas Maret University, Surakarta \\ 2) Faculty of Medicine, Sebelas Maret University, Surakarta \\ 3) Faculty of Education and Sciences, Sebelas Maret University, Surakarta
}

\begin{abstract}
Background: Hypertension is a disease that can lead to stroke, heart attack, heart failure that can lead to death. Someone who has a risk factor for hypertension must be more vigilant and earlier in conducting prevention efforts. Prevention is to control the blood and improve the understanding of hypertension through health education in order to identify and reduce risk behavior hypertension. The purpose of this study was to determine the effect health education program on health behavior in patients with hypertension.
\end{abstract}

Subjects and Method: This was a quasi-experimental study with pretest-posttest and control design. This conducted in Purwo Bakti Husodo, Purwodiningratan and Mojosongo integrated development post Pos Pembinaan Terpadu (Posbindu). A total sample of patients with hypertension as many as 30 people the treatment group and 32 control group. Data analysis using paired sample ttest or Wilcoxon and using independent sample t-test or Mann Whitney.

Results: No effect of hypertension health education to the knowledge of hypertension $(\mathrm{p}<0.001)$. There is an effect on the attitudes of health education hypertension patients with hypertension $(\mathrm{p}=0.014)$. Health education hypertension influence the change risky behavior is a history of smoking $(\mathrm{p}=0.005)$, eating salty foods $(\mathrm{p}=0.008)$ and frequency of exercise ( $\mathrm{p}$ 0.001), while health education hypertension had no effect statistically significant to change risky behavior that is stress $(p=0.322)$ and BMI ( $\mathrm{p}=0.502)$.

Conclusion: Health education about hypertension effect on knowledge, attitudes, smoking, eating salty foods and exercise while no effect on stress and Body Mass Index (BMI).

Keywords: health education, knowledge, attitudes and behavior of hypertension risk.

Correspondence:

Nur Haryani. School of Public Health, Sebelas Maret University, Surakarta.

\section{BACKGROUND}

Humans as social beings in need of health, as this becomes human capital to lead and organize the present and future life better. Seek and always maintain the health of the duty of every human being, starting with self, family, society and the environment. Accord- ing to WHO, the attainment health of people in the world will allow leading a socially and economically productive life. WHO promotion priorities set in 201-2016 include: 1) social determinants of health; 2) The prevention and control of non-communicable disease; 3) the promotion health system; 4) the promotion of sustainable health through 
Journal of Health Promotion and Behavior (2016), 1 (1): 9-18

https://doi.org/10.26911/thejhpb.2016.01.01.02

a partnership approach, the approach to the environment, disaster prevention and postdisaster management (Sulaiman, 2013).

Increasing of morbidity and mortality from non-communicable disease (NCDs) become a serious threat to public health because it adds economic and social burden of family and society.

A hundred patients with non-communicable disease (Penyakit Tidak Menular (PTM), with 70 people do not realize that they suffer from PTM. So they are getting late treatment and make complications, disability and even death. In fact, this incident could have been avoided through risk factor control PTM (Ministry of Health, 2014).

Actually hypertension is included in the group of diseases that can be prevented and managed as early as possible. It is disease with the characteristics of the blood pressure tends to go up and down in a long time, so it requires prolonged treatment may even be lifelong (Triyanto, 2014).

Hypertension is one of the most deadly diseases in the world. One billion people worldwide or one out of four adults suffers from this disease. Even though the number of people with hypertension will increase to 1.6 billion by 2025 (Rudianto, 2013),

Hypertension is a major chronic health that affects nearly one billion adults worldwide. Although the prevalence of hypertension decreased in developed countries, while the prevalence continues to rise in developing countries (Witten et al., 2013). World Health Organization data of $70 \%$ of patients with hypertension are known; $25 \%$ received treatment; $12.5 \%$ were treated (adequately treated cases) is estimated up to 2025. Levels of high blood pressure will increase $60 \%$, and will affect 1,56 billion people around the world. The prevalence of hypertension in Indonesia on urban and rural areas ranges between $17-21 \%$. In Indonesia, national data of patients with hypertension is not detected and generally they are not aware of their condition and (Maharani et al., 2013).

Hypertension occurs in the long term and continuously by stroke, heart attack, heart failure and chronic renal failure. So it should be more vigilant in conducting preventive measures, such as a routine blood pressure control etc (Novian, 2013).

Health behavior change is the best guideline for controlling blood pressure. In addition, patients may be unaware that they have hypertension, because the disease has no symptoms or cause suffering (Jaiyungyuen et al., 2012).

Health education is an effort to deliver message to instill confidence. So people know and understand, also willing and able to do a recommendation expected to improve their health, prevent disease, improve health status, maximize function and the role of patients during illness, helping patients and families cope with problems (Purwati et al., 2014).

Health educations is very important for people with hypertension for getting better understanding of the disease and change their pattern of life in order to achieve a healthy life. Notoatmodjo (2007) states that knowledge or cognitive domain is very important for the formation of a person's actions. Behavior based on knowledge will be more lasting than the behavior that is not based on knowledge. Knowledge must be owned by the patient because the patient is the person most responsible for uncontrolled blood pressure. Based on this, knowledge of 
the factors have a relationship with uncontrolled hypertension blood pressure. The health worker is expected to play a role as well as providing information and monitoring patients with hypertension to address health problems in the community.

Health education in patients with hypertension has been given by health workers, but it has not been able to show significant results. The process of behavior change is influenced by individual. The recapitulation data of PTM in Surakarta in 2013 there were 72,898 patients with hypertension. There are 4,334 Purwodiningratan Sibela health centers with 5,775 patients. Results of preliminary studies on both the health center by conducting interviews with patients seeking treatment shows that complaints from patients are headache up to the nape of the neck, the back of the nape of the neck was sore and irritable. The results also indicate that the interview was due to the onset of symptoms does not restrict foods and less exercise.

Posbindu is involves the participation of community through promotive and preventive efforts to detect and control the presence of early risk factors of PTM. Posbindu activity intended for adults from age 15 and over. They have risk factors for non-communicable disease (smoking, unbalanced diet, obesity, high blood pressure, high cholesterol, lack of physical activity, family history) and adults who do not have risk factor PTM. In the focus of this research focused on this Posbindu because still the assumption that hypertension is only experienced by parents only, but now can strike all ages. But sometimes they do not realize they have hypertension, they usually realize when they do a health check. Therefore it is necessary also anticipation to know what factors that can cause hypertension.

This study aimed to determine the extension of hypertension to change risky behavior in patients with hypertension.

\section{SUBJECTS AND METHOD}

This was a quasi-experimental study with pretest-posttest and control design. This conducted in Posbindu of Purwo Bakti Husodo, Purwodiningratan and Mojosongo. A total sample of patients with hypertension as many as 30 people as the treatment group and 32 control group. Data analysis using paired sample t-test or Wilcoxon and also using independent sample t-test or Mann Whitney.

\section{RESULTS}

Table 1. Effect of knowledge about hypertension before and after health education

\begin{tabular}{|c|c|c|c|c|}
\hline \multicolumn{5}{|c|}{ Treatment Group } \\
\hline Group & SD & Mean & $\mathrm{t}$ & $\mathrm{p}$ \\
\hline Pretest & 1.94 & 15.90 & \multirow{2}{*}{-5.05} & \multirow{2}{*}{$<0.001$} \\
\hline Postest & 1.76 & 17.53 & & \\
\hline \multicolumn{5}{|c|}{ Control Group } \\
\hline Group & SD & Mean & $\mathrm{t}$ & $\mathrm{p}$ \\
\hline Pretest & 16.41 & 16.41 & & \\
\hline Postest & 16.00 & 16.00 & 1.03 & 0.313 \\
\hline
\end{tabular}

Statistical test results in the group treated with paired sample t-test was obtained $\mathrm{p}<0.001$ so that there is influence of health education on knowledge of hypertension. Results of statistical test by paired sample t-test showed $\mathrm{p}=0.313$ so there is no difference in knowledge about hypertension in the control group. 
Journal of Health Promotion and Behavior (2016), 1 (1): 9-18

https://doi.org/10.26911/thejhpb.2016.01.01.02

Table 2. Effect attitude about hypertension before and after health education

\begin{tabular}{lcccc}
\multicolumn{6}{l}{ Treatment Group } \\
\hline Group & SD & Mean & $\mathrm{t}$ & $\mathrm{p}$ \\
\hline Pretest & 6.09 & 67.33 & -2.61 & 0.014 \\
Posttest & 5.94 & 71.10 & & \\
\hline Control Group & & & \\
\hline Group & SD & Mean & $\mathrm{t}$ & $\mathrm{p}$ \\
\hline Pretest & 4.12 & 65.34 & & \\
Posttest & 3.43 & 66.41 & -1.97 & 0.058 \\
\hline
\end{tabular}

The results of the study treatment groups by paired sample t-test were obtained $p=0.014$ so there is the effect of health education on attitudes about hypertension.

Results of statistical test by paired sample t-test showed $\mathrm{p}=0.058$ so that there are differences in attitude about hypertension in the control group.

Table 3. Effect of stress before and after health education

\begin{tabular}{lcccc}
\hline \multicolumn{7}{l}{ Treatment Group } \\
\multicolumn{1}{l}{ Group } & SD & Mean & t & $\mathrm{p}$ \\
\hline Pretest & 12.86 & 32.77 & \multirow{2}{*}{1.01} & 0.322 \\
Posttest & 8.36 & 30.30 & & \\
\hline Control Group & & & \\
\hline Group & SD & Mean & t & $\mathrm{p}$ \\
\hline Pretest & 11.36 & 35.03 & -0.58 & 0.559 \\
Posttest & 9.83 & 33.78 & & \\
\hline
\end{tabular}

The treatment group with paired sample t-test showed $\mathrm{p}=0.322$ so there is no effect of health education on stress as a factor in hypertension risk behavior.

Wilcoxon test results showed statistical $\mathrm{p}=0.559$ so there is no stress on the differences in the control group.

Table 4. Effect of BMI before and after the extension services result of health statistical test group treated with paired sample ttest was obtained $\mathrm{p}=0.502$ so there is no effect of health education on BMI (obesity) as one of the factors of hypertension risk behavior.

Table 4. Effect of BMI before and after health education

\begin{tabular}{lcccc}
\hline \multicolumn{6}{l}{ Treatment Group } \\
\hline Group & SD & Mean & t & p \\
\hline Pretest & 6,38 & 26.85 & \multirow{2}{*}{0.68} & 0.502 \\
Postest & 6,33 & 25.94 & & \\
\hline \multicolumn{6}{l}{ Control Group } & & & \\
\hline Group & SD & Mean & t & p \\
\hline Pretest & 3.77 & 24.94 & \multirow{2}{*}{0.00} & \multirow{2}{*}{.000 } \\
Postest & 3.77 & 24.94 & & \\
\hline
\end{tabular}

Wilcoxon test results showed statistical $\mathrm{p}=1.000$ so that there are no differences in BMI (obesity) in the control group.

Table 5. Effect of smoking behavior before and after health education

\begin{tabular}{ccccc}
\hline \multicolumn{7}{l}{ Treatment Group } & & \\
\hline Group & SD & Mean & $\mathrm{t}$ & $\mathrm{p}$ \\
\hline Pretest & 1.44 & 3.00 & -2.84 & 0.005 \\
Postest & 0.65 & 3.70 & & \\
\hline Control Group & & & \\
\hline Group & SD & Mean & $\mathrm{t}$ & $\mathrm{p}$ \\
\hline Pretest & 0.25 & 3.94 & & \\
Postest & 0.18 & 3.97 & & \\
\hline
\end{tabular}

The test results showed the group treated with Wilcoxon $\mathrm{p}=0.005$ so there is the effect of health education on smoking history as one of the factors of hypertension risk behavior

Wilcoxon test results showed statistical $\mathrm{p}=0.317$ so that there are differences in smoking history in the control group.

Table 6 showed the treatment group with Wilcoxon $\mathrm{p}=0.008$ so there is the effect of health education on diet salty as one of the factors of hypertension risk behavior. 
Wilcoxon test results showed statistical $\mathrm{p}=$ 0.058 so there is no diet in the control group

Table 6. Effect of salty diet before and after the health education

\begin{tabular}{ccccc}
\hline \multicolumn{7}{l}{ Treatment Group } & & & \\
\hline Group & SD & Mean & t & p \\
\hline Pretest & 0.81 & 1.97 & -2.64 & 0.008 \\
Postest & 0.68 & 2.43 & & \\
\hline \multicolumn{6}{l}{ Control Group } & & & \\
\hline Group & SD & Mean & $\mathrm{t}$ & $\mathrm{p}$ \\
\hline Pretest & 0.49 & 1.22 & & \multirow{2}{*}{0.058} \\
Postest & 0.61 & 1.41 & & \\
\hline
\end{tabular}

Table 7. Effect of frequency of exercise before and after health education

\begin{tabular}{|c|c|c|c|c|}
\hline \multicolumn{5}{|c|}{ Treatment Group } \\
\hline Group & SD & Mean & $\mathrm{t}$ & $\mathrm{p}$ \\
\hline Pretest & 0.90 & 1.87 & \multirow{2}{*}{-3.47} & \multirow{2}{*}{0.001} \\
\hline Postest & 0.86 & 2.53 & & \\
\hline \multicolumn{5}{|c|}{ Control Group } \\
\hline Group & $\mathrm{SD}$ & Mean & $\mathrm{t}$ & $\mathrm{p}$ \\
\hline Pretest & 0.68 & 2.09 & \multirow{2}{*}{-1.73} & \multirow{2}{*}{0.083} \\
\hline Postest & 0.69 & 2.19 & & \\
\hline
\end{tabular}

The test results showed the group treated with Wilcoxon $\mathrm{p}=0.001$ so that there are significant health counseling to the frequency of sport as a factor for hypertension risk behavior.

Wilcoxon test results showed statistical $\mathrm{p}=$ 0.083 so there is no difference in the frequency of the control group.

The test results on Table 8 showed the group treated with Wilcoxon $\mathrm{p}=0.147$ so there is no effect of health education on sports time.

Wilcoxon test results showed statistical $\mathrm{p}=0.564$ so there is no difference in exercise time in the control group.
Table 8. Effect of gym time before and after health education.

\begin{tabular}{ccccc}
\hline \multicolumn{6}{l}{ Treatment Group } & & \\
\hline Group & SD & Mean & t & p \\
\hline Pretest & 0.74 & 1.73 & -1.45 & 0.147 \\
Postest & 0.90 & 2.00 & & \\
\hline \multicolumn{2}{l}{ Control Group } & & & \\
\hline Group & SD & Mean & t & p \\
\hline Pretest & 0.62 & 1.75 & -0.58 & 0.564 \\
Postest & 0.61 & 1.78 & & \\
\hline
\end{tabular}

Table 9. Differences in knowledge about hypertension in the treatment group and the control group

\begin{tabular}{ccccc}
\hline Group & SD & Mean & $\mathrm{t}$ & $\mathrm{p}$ \\
\hline Control & 1,30 & 16.00 & \multirow{2}{*}{-3.89} & $<0.001$ \\
Treatment & 1,76 & 17.53 & & \\
\hline
\end{tabular}

Statistical test results with independent sample t-test showed that $\mathrm{p}<0.001$ so that there is a significant difference between the knowledge of hypertension in the treatment group and control group.

Table 10. The difference in attitude in the treatment group and the control group

\begin{tabular}{ccccc}
\hline Group & SD & Mean & $\mathrm{t}$ & $\mathrm{p}$ \\
\hline Control & 3.43 & 66.41 & \multirow{2}{*}{-3.77 } & $<0.001$ \\
Treatment & 5.94 & 71.10 & & \\
\hline
\end{tabular}

Statistical test results with independent sample t-test showed the $\mathrm{p}<0.001$ so that there is a significant difference between the attitudes of hypertension in the treatment group and control group.

Table 11. Differences in stress in the treatment group and the control group

\begin{tabular}{ccccc}
\hline Group & SD & Mean & $\mathrm{Z}$ & $\mathrm{p}$ \\
\hline Control & 9.83 & 33.78 & \multirow{2}{*}{-2.24 } & \multirow{2}{*}{0.025} \\
Treatment & 6.79 & 27.23 & & \\
\hline
\end{tabular}

The test results showed statistically with Mann Whitney $\mathrm{p}=0.025$ so that there is 
Journal of Health Promotion and Behavior (2016), 1 (1): 9-18

https://doi.org/10.26911/thejhpb.2016.01.01.02

a significant difference between the stress in the treatment group and control group.

Table 12. Differences in BMI in the treatment group and the control group

\begin{tabular}{lcccc}
\hline \multicolumn{1}{c}{ Group } & SD & Mean & Z & p \\
\hline Control & 3.77 & 24.94 & -0.89 & 0.371 \\
Treatment & 6.33 & 25.94 & & \\
\hline
\end{tabular}

The test results showed statistically with Mann Whitney $\mathrm{p}=0.371$ so there is no significant difference between BMI in the treatment group and control group.

Table 13. Differences in the smoking history in the treatment group and the control group

\begin{tabular}{ccccc}
\hline Group & SD & Mean & Z & p \\
\hline Control & 0.18 & 3.97 & -2.12 & \multirow{2}{*}{0.034} \\
Treatment & 0.65 & 3.70 & & \\
\hline
\end{tabular}

The test results showed statistically with Mann Whitney $\mathrm{p}=0.034$ so that there is a significant difference between smoking history in the treatment group and control group.

Table 13. Differences salt diet in the treatment group and the control group

\begin{tabular}{ccccc}
\hline Group & SD & Mean & $\mathrm{Z}$ & $\mathrm{p}$ \\
\hline Control & 0.61 & 1.41 & \multirow{2}{*}{-4.91} & $<$ \\
Treatment & 0.68 & 2.43 & & 0.001 \\
\hline
\end{tabular}

The test results showed statistically with Mann Whitney $\mathrm{p}<0.001$ so that there is a significant difference between eating salty foods in the treatment group and control group.

The test results on Table 14 showed statistically with Mann Whitney $\mathrm{p}=0.064$ so there is no significant difference between the frequency of exercise in the treatment group and control group.
Table 14. Differences in the frequency of exercise in the treatment group and the control group

\begin{tabular}{ccccc}
\hline Group & SD & Mean & $\mathrm{Z}$ & $\mathrm{p}$ \\
\hline Control & 0,69 & 2.19 & \multirow{2}{*}{1.86} & \multirow{2}{*}{0.064} \\
Treatment & 0.86 & 2.53 & & \\
\hline
\end{tabular}

Table 15. Differences in exercise time in the treatment group and the control group

\begin{tabular}{ccccc}
\hline Group & SD & Mean & $\mathrm{Z}$ & $\mathrm{p}$ \\
\hline Control & 0.61 & 1.78 & -0.78 & 0.433 \\
Treatment & 0.91 & 2.00 & & \\
\hline
\end{tabular}

Mann Whitney $\mathrm{p}=0.433$ so there is no significant difference between leisure time in the treatment group and control group.

Effect of hypertension extension of knowledge about hypertension. It shows that the extension of hypertension have significant effect on knowledge of hypertension $(<0.001)$ which also confirmed from the results of the average pretest knowledge of hypertension (15.90) while the average posttest (17.53).

It supports the study of Beigi et al., (2014) found no effect of education programs to the changing knowledge. Purwati et al., (2014) in research states there influence the health of health education on knowledge. Sari (2012) states that there is a significant increase in the knowledge that there are significant health education on knowledge,

The results also showed that the average knowledge of hypertension in the control group was (16.00), while the average knowledge in the treatment group was (17.63). This suggests that knowledge of hypertension in the treatment group was higher than in the control group and there are differences in knowledge of the treatment group to the control group ( $\mathrm{p}<0.001)$ so evi- 
dent that health education about hypertension can improve knowledge about hypertension.

Still the respondents who had poor knowledge about hypertension would be a separate issue because it will always be at risk of hypertension because it does not know about risky behavior prevention of hypertension. This is according to a statement from Sunaryo (2006) factors causing health problems are behavioral factors and nonbehavioral factors. Behavioral factors in particular health behavior is influenced by predisposing factors (predisposing factors) which are predisposing factors include people's knowledge on health, tradition and public confidence in the matters relating to the health system of shared values of society, education level, socioeconomic level, work, and so on.

Effect of hypertension extension of the attitude about hypertension. The results show that the extension of hypertension have significant effect on the attitude of hypertension (o.014) which also confirmed from the results of the average pretest attitudes about hypertension (67.33) while the average posttest (71.00). The results support the research Sari (2012) that there are health education influences on the attitudes of people with hypertension.

The results showed the average attitude about hypertension in the control group was (66.41), while the average attitude in the treatment group was (71.10). This shows that the attitude of hypertension in the treatment group was higher than in the control group with $\mathrm{p}<0.001$ so that there is a significant difference between the attitudes of hypertension in the treatment group and control group.
The provision of health education can improve respondents 'attitudes about hypertension, although the majority of respondents' attitudes to the treatment and control groups tend to be negative, it is because hypertension is a disease that is dangerous because it can lead to death so that the respondents still have a tendency to have a negative attitude towards hypertension, even after being given health education experienced an average increase of attitudes became more positive. This is according to a statement in Azwar Allport (2010), that has 4 (four) levels of receiving, responding to, respect and responsibility. Accepting means that the person (subject) want and pay attention to a given stimulus (object), respond to, interpreted to provide answers, when asked, do and accomplish a given task is an indication of the attitude, respect is to invite other people to do or discuss one problem is an indication of the attitude of the three levels and is responsible, which is responsible for everything that has been chosen with all the risks is the attitude of the most high, so that the presence of hypertension experienced respondents needed more liable to have a more positive attitude in an effort to help reduce behavior risk of hypertension.

Effect of hypertension counseling to change risky behavior hypertension. The survey results revealed that there was no effect of health education on stress as a factor in the behavior of hypertension, where the average pretest stress (32.77) while the average post-test (30.30), despite a decline in the provision of health education stress but do not have significant effect in increasing the immunity to stress on respondents. This is due to the occurrence of stress that can be 
Journal of Health Promotion and Behavior (2016), 1 (1): 9-18

https://doi.org/10.26911/thejhpb.2016.01.01.02

influenced by several factors, such is the pressure of work or the occurrence of a problem in the household.

The results showed that there is no effect of health education on BMI (obesity) as a factor of risk behaviors hypertension ( $\mathrm{p}=$ $0.502)$, where the average pretest IMT (26.85) while the average post-test (25.94). The results of this study support Taylor and Wu (2009) that the Body Mass Index (BMI) was relatively unchanged after genetic counseling.

The results showed that there are significant health counseling against smoking history as one of the factors of hypertension risk behaviors ( $\mathrm{p}=0.005)$. According Anggara and Prayitno (2012) stated that cigarette consumption associated with blood pressure. This means pretest smoking history (3.00) while the average posttest (3.70) which means that the respondent reduces the activity of smoking so as to reduce the risk behavior of hypertension.

The results showed that there are significant health counseling on diet salty foods as a factor in risk behaviors hypertension $(\mathrm{p}=0.008)$ with averages of pretest diet (1.97) while the average post-test (2.43).

WHO recommended that the appropriate salt consumption patterns can reduce the risk of hypertension not more than 100 mmol or about $2.4 \mathrm{~g}$ of sodium or $6 \mathrm{~g}$ of salt per day (Anggraini et al., 2009).

The result showed there are significant health counseling to the frequency of sport as a factor for hypertension risk behaviors ( $p=$ o.001) with an average pretest frequency of exercise (1.87) while the average posttest (2.53).

Telephone counseling can significantly increase the changes in health behaviors, with physical activity and vegetable fat intake (Lawler et al., 2012).

Blood pressure increased when doing physical activity regularly. It will be healthier and makes blood pressure be lower than someone who is not doing physical activity. In addition, physical activities were less likely to make a person obese and will raise blood pressure (Suiraoka, 2012).

Physical activity is done properly and regularly, as well as the frequency and length of time used properly can help lower blood pressure. Sports are performed routinely and regularly can reduce the risk factors for coronary heart disease, including hypertension (Simamora, 2012).

The results of the overall research that affects health education to change risky behavior is smoking history, diet salty foods and exercise frequency ( $\mathrm{p}<0.05)$, while health education has no effect on changes in risk behavior is stress and IMT ( $p>0.05)$, this means that the majority of respondents were able to reduce risk behaviors after getting health counseling is to reduce smoking, eating less salty foods, as well as increasing the frequency and time of exercise while on the stress factor, it depends on each individual respondent where stress can happens all the time because of work pressure or family problems while there is no influence IMT obtain any health information for research time does not make observations in the long term

The purpose of health education is to change people's behavior towards healthy behaviors in order to achieve an optimal level of public health, to make it happen, change the expected behavior after receiving counseling cannot happen all at once. Therefore, the achievement of health education is divid 
ed into short-term objective which is to achieve changes in knowledge, medium-term objectives expected result is an increase in understanding, attitudes, and skills that will change behavior toward healthy behaviors, and the long-term goal is to run behavior healthy in their daily lives.

A change in risk behavior in hypertensive patients is also due to the figures that influence, namely the figures that provide health education. This is according to a statement from Sunaryo (2006) that the factors affecting the behavior is a contributing factor (reinforcing factors) which of them is the attitude and behavior of health care workers.

The conclusion from this study that there is influence hypertension extension to the knowledge of hypertension in patients with hypertension

No effect on the attitudes of extension of hypertension in patients with hypertension. Extension of hypertension influence the change risky behaviors include smoking history, diet and exercise frequency salty while counseling hypertension has no statistically significant effect against stress and IMT.

\section{REFERENCE}

Anggraini AD, Waren A, Situmorang E, Asputra H, Siahaan SS (2009). FactorsFactors Associated With Hypertension Patients The Genesis Treatment In Adult Health Center Clinic Bangkinang From January until June 2008. Pekanbaru in Riau: Faculty of Medicine University of Riau
Azwar S (2010). Human Attitude Theory and Measurement. Yogyakarta: Student Library.

Beavers DG (2009). Blood Pressure. Jakarta: Dian Rakyat.

Jaiyungyuen U, Suwonnaroop N, Priyatruk P, Moopayak K (2012). Factors Influenceing Health-Promoting Behaviors of elderly With Hypertension. 1st Mae Fah Luang University International Conference: $1-9$.

Ministry of Health (2014). Book Smart Kader: Non-Communicable Diseases. Series 4. Jakarta: Directorate General of Disease Control and Environmental Health.

Lawler SP, Winkler E, Reeves MM, Owen N, Graves N, Eakin EG (2010). Multiple Health Behavior Changes and Covariation in a Telephone Counseling Trial. Annals of Behavioral Medicine 39 (3): 257.

Maharani, Chaeruddin, Darmawan S (2013). Effects of Health Education Against Public Knowledge About Hypertension Disease in the Village District of Mattiro Sompe Patobong Pinrang 3 (1): 146150.

Novian A (2013). Compliance Diet Hypertension Patients. Journal of Public Health 9 (1): 100-105.

Purwati RD, Bidjuini H, Babakal A (2014). Influence of Health Education Behavioral Sciences Clients Against Hypertension In Puskesmas Shoulder Manado. Manado: Nursing Science Program Faculty of Medicine, University of Sam Ratulangi.

Rudianto BF (2003). Conquering Hypertension and Diabetes: Detecting, Preventing and Treating Alternative 
Journal of Health Promotion and Behavior (2016), 1 (1): 9-18

https://doi.org/10.26911/thejhpb.2016.01.01.02

andHerbal Medical. Yogyakarta: Sakkhasukma.

Simamora JP (2012). Effect of Characteristics and Adult Lifestyle Group Associate Genesis Against Hypertension In Puskesmas Matiti Humbang Hasundutan. Thesis. Terrain: Graduate University of North Sumatra.

Sulaiman ES (2013). Health Promotion: Theory and Implementation in Indonesia. Surakarta: UNS Press.

Sunaryo (2006). Psychology for Nursing. Jakarta: EGC
Triyanto E (2014). Nursing Services for: Patients with Hypertension Integrated. Yogyakarta: Graha Science.

Zuraidah, Maksuk, Apriliadi N (2012). Analysis of Disease Risk Factors Hypertension Society in the District of Kota Kemuning Palembang 2012. Health Manpower Development Research. Palembang: The Ministry of Health of the Republic of Indonesia Polytechnic of Health of Palembang. 